\title{
Jejunal absorption rates of glucose, glycine and glycylglycine in Zambian African adults with malnutrition
}

\author{
By G. C. COOK \\ Department of Medicine, The University of Zambia, PO Box RW I Io, \\ Lusaka, Zambia
}

(Received I I October 1973 - Accepted 18 fanuary 1974)

\begin{abstract}
I. Absorption rates of glucose (from a $200 \mathrm{~mm}$ solution), glycine (from a roo mm solution), and glycylglycine (from a $50 \mathrm{mM}$ solution) have been estimated in six Zambian African adults with clinical evidence of malnutrition. A double-lumen tube technique was used to determine absorption rates from a $300 \mathrm{~mm}$ section of jejunum in vivo.

2. Two of the subjects had ileal tuberculosis and Kaposi's sarcoma respectively. A third probably had abdominal tuberculosis. Three of them had pellagra. Mean serum albumin concentration was 24 (14-43) g/l. Absorption rates have been compared with those in Zambian Africans (control subjects), previously studied, who had no clinical evidence of malnutrition, systemic infection or of gastrointestinal disease.

3. Mean glucose, glycine and glycylglycine absorption rates in the malnourished subjects were not significantly different from those in the control subjects. Mean net water absorption rate from the glucose solution was similar in the malnourished subjects and controls; during the glycine and glycylglycine perfusions the mean net absorption rate was, however, significantly lower in the malnourished subjects $(P<0.01$ and $P<0.05$ respectively); mean net water transfer during the glycine perfusions was towards the jejunal lumen in the malnourished subjects. One subject with pellagra had an abnormal excretion of $\mathrm{D}$-xylose after a $25 \mathrm{~g}$ oral load; all other tests were normal.

4. It seems probable that malnutrition must be very severe, with jejunal mucosal abnormalities, before absorption rates of glucose, glycine and glycylglycine are significantly altered. The present study does not support the view that subclinical malnutrition is important in producing malabsorption of dietary components in Zambian African subjects. Systemic bacterial infections, and raised serum $\gamma$-globulin and immunoglobulin IgG concentrations have previously been associated with an impairment of glucose absorption rate in Zambian African subjects; those factors seem much more likely than subclinical malnutrition to be relevant, in the context of absorption, in the pathogenesis of overt malnutrition.
\end{abstract}

Several investigators have studied the effect of malnutrition on the intestinal absorption of monosaccharides, amino acids and peptides in experimental animals and man, but results have often been conflicting. Inhibition of glucose absorption from the small intestine of the rat after a $3 \mathrm{~d}$ fast (Newey, Sanford \& Smyth, I970), stimulation in the semi-starved rat (Kershaw, Neame \& Wiseman, r960) and guinea-pig (Hindmarsh, Kilby, Ross \& Wiseman, 1967) and no significant effect in the semistarved hamster (Hindmarsh et al. 1967) have variously been reported. In vivo studies in malnourished children have shown an inhibition of glucose absorption rate from the jejunum (James, I968). Similarly, some experiments on rat intestine have shown an inhibition of free amino acid transfer during dietary restriction (Levin, Newey \& Smyth, 1965; Newey et al. 1970), while others have shown either a stimulation (Kershaw et al. I960; Hindmarsh et al. 1967; Kirsch, Saunders \& Brock, I968; Steiner \& Gray, 1969) or no effect (Neale, 197r). In man, Adibi \& Allen (r970) showed in an in vivo study a significant decrease in the absorption rate of eight essential amino acids after 2 weeks of total starvation or an isoenergetic protein-free diet. Steiner, 
Farrish \& Gray (1969) demonstrated in vitro, a relative decrease in L-valine uptake by jejunal biopsy-specimens from six obese subjects after a 2-week fast; however there was no significant change in three subjects after protein deprivation. Results for dipeptide absorption in association with malnutrition are limited. Although dietary restriction for $10 \mathrm{~d}$ in the rat increased the absorption of methionine, that of the dipeptide was not altered (Lis, Crampton \& Matthews, 1972). In $4 \mathrm{~d}$ starved rats although free $\mathrm{L}$-valine absorption was increased, absorption from casein hydrolysate was unaltered (Steiner \& Gray, 1969). After protein deprivation for $40 \mathrm{~d}$, decreased absorption of an amino acid mixture but no alteration in that of a pancreatic hydrolysate was demonstrated (Lis, Matthews \& Crampton, I972).

In Lusaka, although childhood malnutrition is common, adults are usually fairly well nourished; pellagra and folate deficiency are occasional problems. The present investigation was designed to study glucose, glycine and glycylglycine absorption rates from the jejunum of six malnourished adult Zambian Africans in vivo. In three subjects the malnutrition was secondary to another disease; the other three had pellagra.

\section{EXPERIMENTAL}

\section{Subjects studied}

Table I gives details of the six Zambian African adults studied. They were all inpatients at The University Teaching Hospital, Lusaka. They agreed to undergo investigation which was done 3-I4 (mean 6) $\mathrm{d}$ after admission, following full explanation through an interpreter. None had previously been investigated. All of them had evidence of undernutrition, either primary or secondary to an underlying disease. History of disease varied from a few days to I year. Diarrhoea had been a prominent feature in subjects $1,2,3$ and 5 and no. 5 also had a moderately severe dementia on admission. Diet had been grossly inadequate for subjects I and 4 ; subjects $3,4,5$ and $6 \mathrm{had}$ an excessive alcohol intake in the form of locally produced beer. All had skin changes of undernutrition; in subjects 4,5 and 6 classical evidence of pellagra was present. Subjects I, 2 and 3 had fine straight depigmented hair. Subjects I, 2, 3 and 6 had clinical evidence of fluid retention; subject $\mathrm{I}$ had ascites. Subjects I, 2, 4 and 5 had hepatomegaly, and subject no. 2 had splenomegaly. Only one subject (no. I) was pyrexial at investigation. Subject I had a megaloblastic anaemia, confirmed by bone-marrow examination; erythropoiesis was normoblastic in the others. Mean serum immunoglobulin concentrations were $(\mathrm{mg} / \mathrm{ml})$ : IgG I 8 (14-24), $\operatorname{IgA} 3.5$ $(\mathrm{I} \cdot \mathrm{I}-7 \cdot 0)$, IgM I.7 $(0 \cdot 6-2 \cdot 4)$, and $\operatorname{IgD} 0 \cdot 09(0 \cdot 04-0 \cdot 25)$. Mean serum urea was $4 \cdot 15$ $(2 \cdot 82-5 \cdot 48) \mathrm{mmol} / \mathrm{l}$. Tests of liver function (serum bilirubin, glutamic-oxaloacetic and glutamic-pyruvic transaminases ( $E C$ 2.6. I I and 2.6. I .2 respectively) and alkaline phosphatase $(E C$ 3.1.3.1)) were normal in all subjects. Aspiration liver biopsy specimens were obtained from subjects $\mathrm{I}$ and 2 . They both showed fatty infiltration which was gross in subject I (Fig. r), and that from subject 2 contained bilharzia granulomata. A barium meal given to subject 2 showed multiple ileal strictures and a diagnosis of tuberculosis was confirmed at laparotomy. Although subject I probably had underlying abdominal tuberculosis, she subsequently died despite 2 weeks of 
Vol. $3^{2}$

总

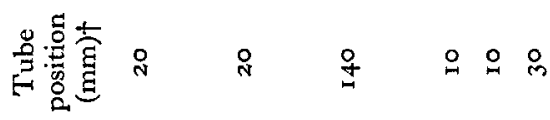

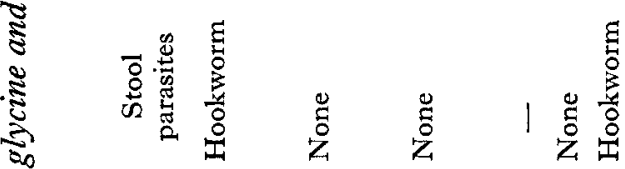

总

䆖

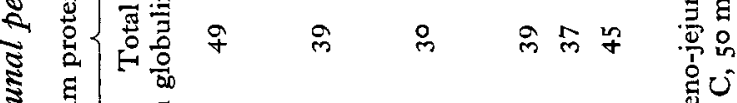

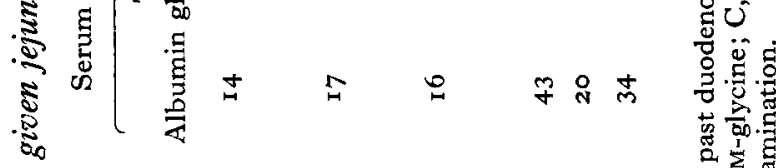

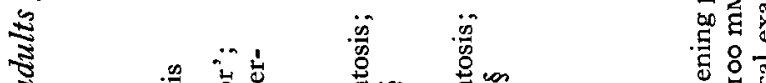

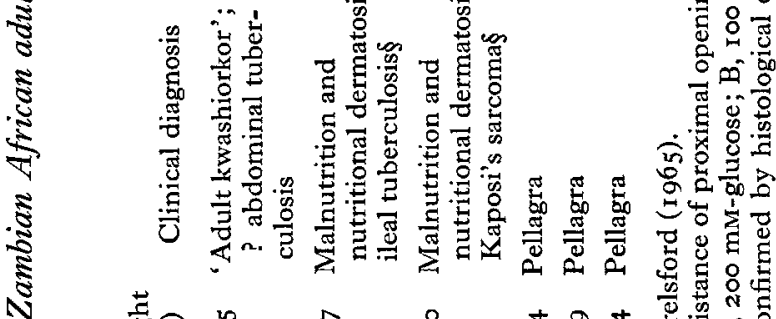

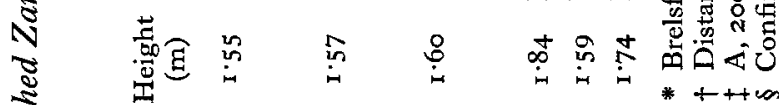

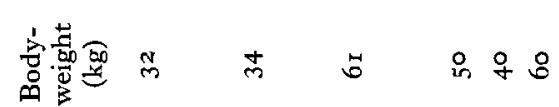

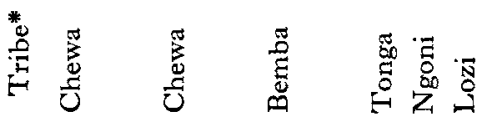

离 ot ot to to ot to

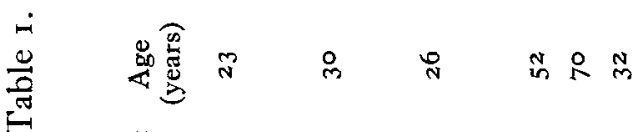

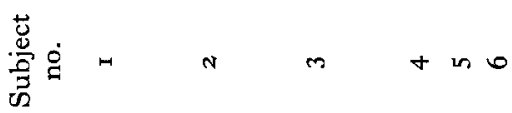




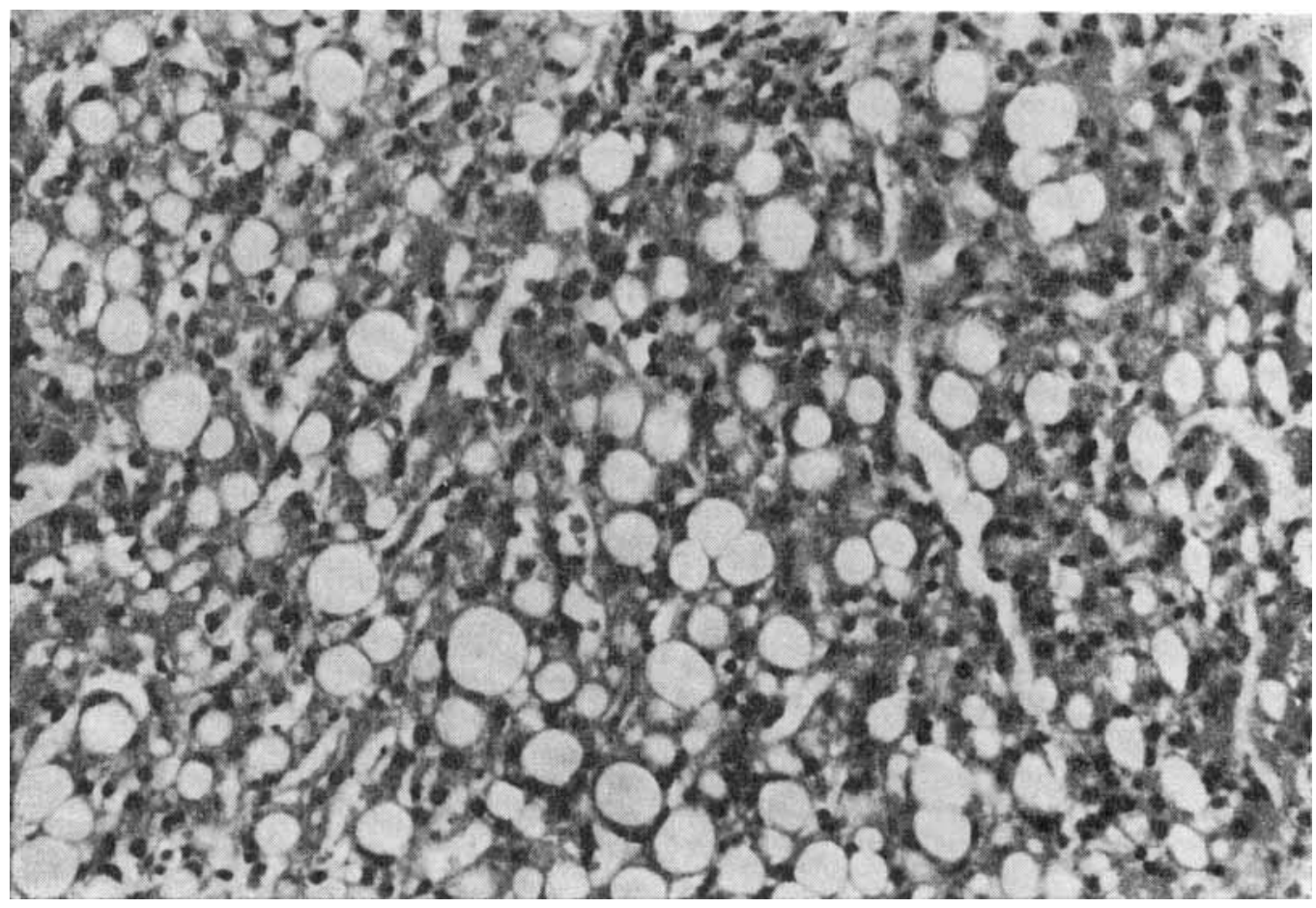

Fig. I. Aspiration liver biopsy sample taken from subject no. I showing gross fatty change of the hepatocytes. Stained with haemotoxylin and cosin and magnified approximately 300 times.

anti-tuberculous therapy; post-mortem examination was not performed. Subjects I, 2, 3 and 6 had had no specific treatment before investigation; subjects 4 and 5 had received oral vitamin $B$ preparations.

Biopsy specimens were obtained in the six subjects from the first $200 \mathrm{~mm}$ of jejunum as described by Cook \& Kajubi (ig66); all gave results for dissecting-microscope appearance in the fresh state, histology and disaccharidase concentrations, which were normal for African subjects (Cook, Kajubi \& Lee, 1969; Cook, Asp \& Dahlqvist, I973; G. C. Cook, N.-G. Asp, N. O. Berg and A. Dahlqvist, unpublished results).

Table 2 gives details of the control subjects. All were Zambian African adults. None of them had clinical evidence of malnutrition, systemic infection or of gastrointestinal disease. The results in the subjects who had glucose perfusions have been reported by Cook (1971 $a, 1972 a, b, 1973 a$ ), those in the subjects who had glycine perfusions by Cook (1971 $a, 1972 b, 1973 c)$ and those in the subjects who had glycylglycine perfusions by Cook (1972 $b, 1973 c, 1974 a)$.

\section{Perfusion technique}

Jejunal absorption was studied after a $12-14 \mathrm{~h}$ overnight fast, during which sips of water were permitted. Details of the technique have been described by Cook ( $197 \mathrm{r} a, b, 1972 a, b)$. A double-lumen tube which contained an opening into one lumen, $300 \mathrm{~mm}$ from the end, and three openings into the other lumen, at the distal end, 
Vol. 32

(1)

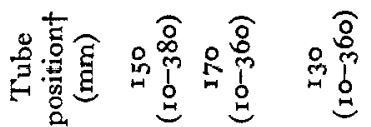

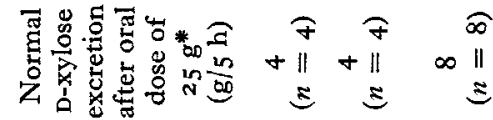

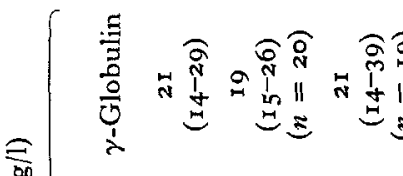

क्ष

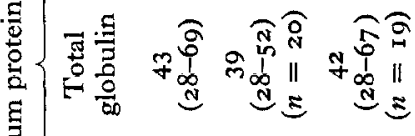

\&. है

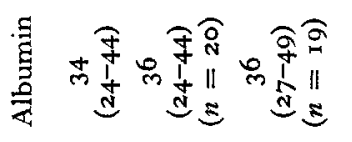

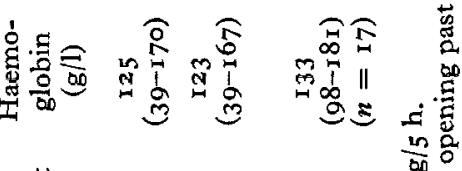

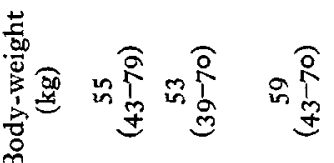

in

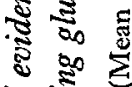

$\overrightarrow{8}$

.

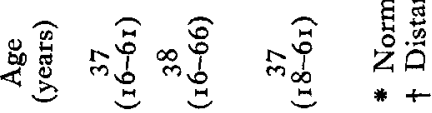

$\frac{2}{8}$

की $\left\{\begin{array}{lll}\text { of } N \text { in } & 0 \\ \text { ro } & =0\end{array}\right.$

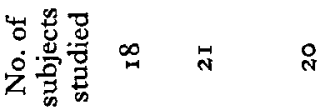

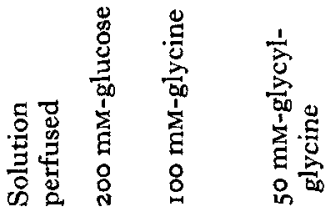


was used; the position of the proximal (infusion) opening past the duodeno-jejunal flexure is shown in Table $x$. In no instance had the tube moved by more than $100 \mathrm{~mm}$ in a distal direction by the end of the investigation. Three perfusion solutions which contained: A, $200 \mathrm{mM}$-glucose; $\mathrm{B}$, $100 \mathrm{mM}$-glycine and $\mathrm{C}$, $50 \mathrm{mM}$-glycylglycine were pumped through the proximal opening of the tube at a constant rate of $12 \mathrm{ml} / \mathrm{min}$. All solutions were made iso-osmotic by adding $\mathrm{NaCl}$, and they all contained $5 \mathrm{~g}$ polyethylene glycol (PEG; molecular weight 4000)/1 as a non-absorbable marker. The sequence of the infusions was varied in the different subjects (Table I). After an equilibration period of $35 \mathrm{~min}$, three successive $10 \mathrm{~min}$ collections of intestinal contents were made by siphoning via the distal opening. Perfusion with the three solutions followed directly after each other. The technique in the control subjects was identical.

\section{Analytical methods and calculation of results}

Processing of the specimens and analytical methods for the estimation of glycine, glycylglycine and PEG have been described (Cook, 1971 $a, b, 1972 a, b, 1973 c$ ). For the glucose estimations a glucose-oxidase kit (Boehringer GmbH, Mannheim, W. Germany) was used. Determinations of glucose and PEG were made in duplicate and those for glycine and glycylglycine in triplicate. In each instance specimens of the perfusion fluids were estimated for all of their constituents after processing in an identical way to that of the test samples. All specimens containing glycylglycine were estimated for free glycine before and after hydrolysis with 2 vol. $6 \mathrm{M}-\mathrm{HCl}$ in sealed tubes at $110^{\circ}$ for $16 \mathrm{~h}$. The rates of absorption of glucose, glycine, glycylglycine and net water transfer were calculated using standard formulas (Cook, $197 \mathrm{I} a, b, \mathrm{I} 972 a, b$ ). The methods for the control subjects were identical.

Serum proteins were determined as previously described (Cook, 1973 $d$ ) on fasting specimens taken on the day of the absorption studies. Serum immunoglobulin concentrations were determined using immunodiffusion plates (Meloy Laboratories Inc., Springfield, Virginia, USA). D-Xylose excretion after a $25 \mathrm{~g}$ oral load and serum urea concentrations were determined as described by Cook (I972c); the subjects were carefully supervised throughout the $5 \mathrm{~h}$ urine collection period.

\section{RESULTS}

All of the subjects had diarrhoea consisting of $\mathrm{I}-3$ fluid stools after the perfusion study. Subjects 3 and 5 also had a fluid stool at approximately $\mathrm{I}$ h before the end of the investigation.

Table 3 gives results of absorption rates of glucose, glycine and glycylglycine in the six malnourished subjects. Reproducibility of the results for absorption rates during the three Io min collection periods was calculated as described by Cook (1972a). For glucose absorption rate the SD was $0.02 \mathrm{~g} / \mathrm{min}$ per $300 \mathrm{~mm}$ jejunum and the coefficient of variation was $0.094(n=6)$. For glycine absorption rate, the corresponding values were $6.3 \mathrm{mg} / \mathrm{min}$ per $300 \mathrm{~mm}$ jejunum and $0.149(n=6)$. For glycine absorption rate from glycylglycine, the values were $6.5 \mathrm{mg} / \mathrm{min}$ per $300 \mathrm{~mm}$ jejunum and $0 . \mathrm{I}_{5}$ $(n=6)$. For net water absorption rate the SD was $\mathrm{I} \cdot 53 \mathrm{ml} / \mathrm{min}$ per $300 \mathrm{~mm}$ jejunum $(n=\mathrm{I} 8)$. 
Table 3. Absorption rates and D-xylose excretion in six malnourished subjects given jejunal perfusions of $200 \mathrm{mM}$-glucose, roo $\mathrm{mm}$-glycine and $50 \mathrm{~mm}$-glycylglycine

Jejunal absorption rate $(\mathrm{mg} / \mathrm{min}$ per $300 \mathrm{~mm}$

\begin{tabular}{|c|c|c|c|c|}
\hline \multirow[b]{2}{*}{ Subject no. } & \multicolumn{3}{|c|}{$\begin{array}{c}\text { Jejunal absorption rate }(\mathrm{mg} / \mathrm{min} \text { per } 300 \mathrm{~mm} \\
\text { jejunum) of }\end{array}$} & \multirow{2}{*}{$\begin{array}{c}\text { D-Xylose excretion } \\
\text { after oral dose of } \\
25 \mathrm{~g}(\mathrm{~g} / 5 \mathrm{~h})\end{array}$} \\
\hline & Glucose & Glycine & $\begin{array}{l}\text { Glycine from } \\
\text { glycylglycine }\end{array}$ & \\
\hline I & 0.23 & 45 & 60 & $6 \cdot 3$ \\
\hline 2 & 0.17 & 37 & 52 & $7 \cdot 0$ \\
\hline 3 & 0.26 & 42 & 53 & $5 \cdot 7$ \\
\hline 4 & 0.26 & $5 \mathrm{I}$ & 65 & $5 \cdot 4$ \\
\hline 5 & 0.19 & 33 & 44 & $2 \cdot 5$ \\
\hline 6 & 0.23 & 47 & 65 & $5 \cdot 8$ \\
\hline
\end{tabular}

Table 4. Mean rates of absorption of glucose (from a $200 \mathrm{mM}$ solution), glycine (from a I00 $\mathrm{mM}$ solution), and glycine (from a $50 \mathrm{mM}$ glycylglycine solution) from a $300 \mathrm{~mm}$ section of jejunum in malnourished subjects $\dagger$ and in control subjectst, together with corresponding rates of net water absorption

\begin{tabular}{|c|c|c|c|c|c|c|}
\hline \multirow{2}{*}{$\begin{array}{c}\text { Absorption rate } \\
\text { (/min per } 300 \mathrm{~mm} \text { jejunum) }\end{array}$} & \multicolumn{3}{|c|}{ Malnourished } & \multicolumn{3}{|c|}{ Controls } \\
\hline & Mean & SEM & Range & Mean & SEM & Range \\
\hline Glucose (g) & 0.223 & 0.014 & $0.17-0.26$ & 0.227 & 0.010 & $0.15-0.35$ \\
\hline Water (ml) & $1 \cdot 76$ & 0.23 & $0.8 I-2.53$ & $I \cdot 88$ & 0.32 & $-x \cdot 15-4.72$ \\
\hline Glycine (mg) & 42 & $2 \cdot 7$ & $33-5 \mathrm{I}$ & 49 & $2 \cdot 3$ & 16-6o \\
\hline Water $(\mathrm{ml})^{* *}$ & -0.42 & 0.25 & $-I \cdot 19-0 \cdot 19$ & $\mathrm{I} \cdot 52$ & 0.32 & $-3 \cdot 57-3 \cdot 16$ \\
\hline $\begin{array}{l}\text { Glycine from glycyl- } \\
\text { glycine (mg) }\end{array}$ & 56 & $3 \cdot 4$ & $44-65$ & 66 & $3 \cdot 0$ & $3^{8-83}$ \\
\hline Water (ml)* & 0.06 & 0.68 & $-2 \div 94-I \cdot 21$ & $I \cdot 46$ & 0.34 & $-1 \cdot 74-3 \cdot 66$ \\
\hline
\end{tabular}

Mean value for the malnourished subjects is significantly less than that for the control subjects:

* $t 2.09,24 \mathrm{df}, P<0.05$; ** $t 3.17,25 \mathrm{df}, P<0.01$.

+ Six patients in each study.

Eighteen subjects for glucose, twenty-one subjects for glycine and twenty subjects for glycylglycine.

Table 4 shows comparative results for glucose, glycine and glycylglycine absorption rates in the six malnourished subjects and the control subjects. None of the differences between the means was significant by Student's $t$ test. Table 4 also summarizes results for net water transfer. The mean rates during the glycine and glycylglycine perfusions were significantly lower in the malnourished subjects compared with those in the control subjects. Correlations between serum albumin concentrations and water absorption rates from the three perfusion solutions were not significant (for glucose, $r=+0.037$; for glycine, $r=+0.321$; and for glycylglycine, $r=+0.407$ ).

The mean rate of glycine absorption from glycylglycine was significantly higher than that from glycine in the six subjects $\left(t_{12} \cdot 7^{8}, 5 \mathrm{df}, P<0.00 \mathrm{I}\right.$, paired $t$ test). The mean rate of luminal disappearance of glycylglycine was $68.0 \mathrm{mg}$ glycine $/ \mathrm{min}$ per $300 \mathrm{~mm}$ jejunum, which was significantly higher than the mean rate of glycylglycine absorption (mg glycine/min per $300 \mathrm{~mm}$ jejunum) $(t .44,5 \mathrm{df}, P<0.01$, paired $t$ test).

Table 3 gives results for $\mathrm{D}-\mathrm{xylose}$ excretion $(\mathrm{g} / 5 \mathrm{~h})$. 


\section{DISCUSSION}

The study shows that mean absorption rates of glucose, glycine and glycylglycine in the malnourished subjects were not significantly different from those in the control subjects. The malnourished subjects had started a hospital diet by the time of the investigations and some were receiving other forms of treatment, but nevertheless clinical evidence of malnutrition was present in all of them and serum albumin in four was between 14 and $20 \mathrm{~g} / 1$. It would have been unethical not to have started some form of treatment very soon after admission. Jejunal biopsies were normal for African subjects in Africa (Cook et al. 1969; Cook et al. 1973). It seems from this study that significant malabsorption does not occur in association with malnutrition unless marked mucosal changes, which are occasionally seen in severe kwashiorkor (Burman, I965; Stanfield, Hutt \& Tunnicliffe, I965), are present. The concentrations of glucose, glycine and glycylglycine in the perfusion solutions were higher than are likely to be present in the human jejunum in vivo; however, values for such concentrations are scanty. In man, Borgström, Dahlqvist, Lundh \& Sjövall (1957) demonstrated glucose concentrations of $28-700$ (mean 250 ) $\mathrm{mmol} / \mathrm{l}$ at the duodeno-jejunal flexure after a test meal, but Olsen \& Ingelfinger (I 968 ) found concentrations of $20-40 \mathrm{mmol} / \mathrm{l}$ after a carbohydrate meal.

Using a perfusion system in vivo, James (1968) has demonstrated an impaired jejunal glucose absorption rate in five malnourished Jamaican children; the rate increased after treatment. Results from the present study are at variance with that observation; it is probable, however, that the subjects studied by James had more severe malnutrition and may also have had infections. Animal experiments, in most instances in vitro, have given variable results and are difficult to interpret (Wiseman, 197r). In a group of Zambian African subjects who had no evidence of malnutrition or systemic infection there was no association between glucose absorption rate and serum albumin concentration, but a significant inverse correlation between glucose absorption rate and serum total globulin $(P<0.02)$ and $\gamma$-globulin $(P<0.01)$ concentration (Cook, I973d). A significant inverse correlation between glucose absorption rate and $\mathrm{D}$-xylose absorption and serum $\mathrm{IgG}$ concentration has recently been demonstrated in a similar group of Zambian African subjects (Cook, 1974b). Zambian African subjects with systemic bacterial infections have an impairment of mean glucose absorption rate from the jejunum (Cook, $197 \mathrm{r} b$ ); however that seems to be related to the raised serum $\gamma$-globulin and IgG concentrations rather than the infection per se. Although subjects $\mathrm{I}$ and 2 in the present study had evidence of infections, their serum $\gamma$-globulin and IgG concentrations were within the normal range for African subjects in Lusaka: 24 and $\mathrm{I} 7 \mathrm{~g} / \mathrm{l}$, and $\mathrm{I} 9$ and $\mathrm{I} 4 \mathrm{mg} / \mathrm{ml}$ respectively. It seems probable, therefore, that systemic infections, associated with elevated serum IgG concentrations, are more important than malnutrition in the pathogenesis of glucose malabsorption.

For glycine absorption, although the mean rate was lower in the malnourished subjects compared with the control subjects, the difference between the means was not significant. A significant reduction in amino acid absorption rate after a 2-week fast has been demonstrated in man in vivo by Adibi \& Allen (1970). An in vitro study 
in man has shown either a relative decrease or no significant effect in L-valine uptake by intestinal mucosa after 2 weeks of starvation (Steiner et al. 1969). In vitro studies on jejunal mucosa specimens from five children with kwashiorkor showed a normal uptake of lysine and alanine (Woodd-Walker, Hansen \& Saunders, 1972). Animal experiments have yielded conflicting results. A significant positive correlation between glycine absorption rate, and serum total globulin $(P<0.01)^{\prime}$ and $\gamma$-globulin $(P<0.05)$ concentrations has previously been shown in a group of Zambian African subjects who had no evidence of malnutrition or systemic infection (Cook, $1973 b$ ).

The mean rate of glycine absorption from glycylglycine was lower in the malnourished subjects than in the control subjects but the difference in the means was also not significant. Results from animal experiments have indicated that peptide absorption is not significantly influenced by short- or long-term dietary restriction (Lis, Crampton \& Matthews, 1972; Lis, Matthews \& Crampton, 1972). Depression of dipeptide hydrolase activity has however been shown in the malnourished rat (Kumar \& Chase, 1971), and in both the monkey (Kumar \& Chase, 1972) and in children (Kumar, Ghai \& Chase, I97I) a significant decrease in the activities of some dipeptidases has been reported in association with undernutrition. In the latter two studies severe jejunal mucosa damage was however also present. In the present study the jejunum was morphologically normal; studies of more subjects would be required before a significant depression in glycylglycine absorption due to a deficiency of glycylglycine dipeptidase activity could be demonstrated. The rate of glycine absorption from glycylglycine in the malnourished subjects was significantly higher than that of glycine absorption from glycine $(P<0.001)$. A similar result was obtained in a group of well-nourished subjects (Cook, $1972 c$ ) and is consistent with the finding that glycine and glycylglycine are transferred by jejunal mechanisms which are partly and possibly wholly separate (Cook, I973c). The mean rate of glycine absorption was significantly lower than that for free glycine production from glycylglycine in the jejunal lumen. That observation indicates that there is back-diffusion of hydrolysed glycine to the jejunal lumen, the extent of which is similar to that in a group of wellnourished subjects; approximately $20 \%(\mathrm{Cook}, 1973 b)$. Some glycylglycine dipeptidase activity is presumably situated near the luminal pole of the enterocyte (Peters, 1970).

The mean net water transfer rate in the malnourished subjects was significantly lower than that in the control subjects during the glycine and glycylglycine perfusions; during the glycine perfusions there was in fact a mean net transfer towards the lumen and during the glycyglycine perfusions the mean was close to zero. The perfusion method used, without proximal luminal occlusion, gives less good reproducibility for net water transfer than for solutes (Cook, $1972 a, b$ ). However, the present results strongly suggest that the subjects with malnutrition had a defect in water transfer from the solutions with lower solute concentrations. In subjects with cholera, an oral glycine or glucose solution has been shown to improve hydration by increasing water absorption (Nalin, Cash, Rahman \& Yunus, 1970); the present results suggest that for net water absorption to occur in malnourished subjects there must be rapid solute absorption, since at lower absorption rates net transfer of water to the lumen has been observed. Subject 2 in the present study had ileal tuberculosis; she seemed to be eating 
a fairly good diet, which consisted mainly of carbohydrate, and jejunal absorption was relatively normal. It is not clear therefore why weight loss was so gross; it seems unlikely that it was entirely associated with hypercatabolism associated with the infection. Tuberculous ileo-colitis is a relatively common disease in Africa (Francis, 1972; Lewis \& Kolawole, 1972) and is probably under-diagnosed. Subject 3 had disseminated Kaposi's sarcoma (Taylor \& Kyalwazi, 1972). His normal absorption rates suggest that gross weight loss in malignant disease is not associated with an absorption defect, unless the intestinal mucosa or digestive organs are involved, or the serum IgG is elevated. Subjects $4^{-6}$ had pellagra; however only one, no. 5, had had diarrhoea. In India, abnormal absorption in association with pellagra is thought to be common; in one study twenty-two of twenty-four subjects showed evidence of malabsorption (Mehta, Kaur, Avasthi, Wig \& Chhuttani, 1972). In Egypt a high incidence has also been claimed (Halsted, Sheir, Sourial \& Patwardhan, I969). However, both studies probably failed to take adequate account of normal values for those population groups.

I am grateful to Dr P. O. Chuke (for subject I) and Dr E. N. Obineche (for subjects 4, 5 and 6) for allowing me to study patients admitted under their care, and to $\mathrm{Mr}$ James Tembo for explaining the procedures and for his help during the investigations. I am also grateful to Dr J. U. Egere for dermatological opinions. The Reverend W. H. Woodhouse made a generous financial contribution to this project.

\section{REFERENCES}

Adibi, S. A. \& Allen, E. R. (1970). Gastroenterology 59, 404.

Borgström, B., Dahlqvist, A., Lundh, G. \& Sjövall, J. (1957). F. clin. Invest. 36, I52 1.

Brelsford, W. V. (1965). The Tribes of Zambia. Lusaka: Government Printer.

Burman, D. (1965). Archs Dis. Childh. 40, 526.

Cook, G. C. (1971 a).F. Physiol., Lond. 217,61.

Cook, G. C. (1971 b). Gut 12, 1001.

Cook, G. C. (1972a). Clin. Sci. 42, 525.

Cook, G. C. (1972b). Clin. Sci. 43, 443.

Cook, G. C. (1 $972 c$ ). Am. F. clin. Nutr. 25, 490.

Cook, G. C. (1973a). Clin. Sci. 44, 425.

Cook, G. C. $(1973 b)$. Br. F. Nutr. 29, 377.

Cook, G. C. (1973c). Br. 手. Nutr. 30, 13.

Cook, G. C. (1973d). Nature, Lond. 241, 284.

Cook, G. C. (1974a). Br. F. Nutr. 32, 163.

Cook, G. C. (1974b). Br. med. $\mathcal{F}$. (In the Press.)

Cook, G. C., Asp, N.-G. \& Dahlqvist, A. (1973). Gastroenterology 64, 405.

Cook, G. C. \& Kajubi, S. K. ( 1966$)$. Lancet i, 725.

Cook, G. C., Kajubi, S. K. \& Lee, F. D. (1969). F. Path. 98, 157.

Francis, T. I. (I972). Trop. geogr. Med. 24, 232.

Halsted, C. H., Sheir, S., Sourial, N. \& Patwardhan, V. N. (1969). Am. F. clin. Nutr. 22, 744.

Hindmarsh, J. T., Kilby, D., Ross, B. \& Wiseman, G. (1967). F. Physiol., Lond. r88, 207.

James, W. P. T. (1968). Lancet i, 333 .

Kershaw, T. G., Neame, K. D. \& Wiseman, G. (1960). F. Physiol., Lond. 152, 82.

Kirsch, R. E., Saunders, S. J. \& Brock, J. F. (1968). Am. F. clin. Nutr. 21, 1302.

Kumar, V. \& Chase, H. P. (1971). F. Nutr. 101, I509.

Kumar, V. \& Chase, H. P. (1972). Am. F. clin. Nutr. 25, 485.

Kumar, V., Ghai, O. P. \& Chase, H. P. (I97I). Archs Dis. Childh. 46, 80 I.

Levin, R. J., Newey, H. \& Smyth, D. H. (1965). F. Physiol., Lond. 177, 58.

Lewis, E. A. \& Kolawole, T. M. (1972). Gut r3, 646 . 
Lis, M. T., Crampton, R. F. \& Matthews, D. M. (1972). Br. F. Nutr. 27, I 59.

Lis, M. T., Matthews, D. M. \& Crampton, R. F. (1972). Br. $\mathscr{F}$. Nutr. 28, 443.

Mehta, S. K., Kaur, S., Avasthi, G., Wig, N. N. \& Chhuttani, P. N. (1972). Am. F. clin. Nutr. 25, $545 \cdot$

Nalin, D. R., Cash, R. A., Rahman, M. \& Yunus, Md. (I 970). Gut 11, 768.

Neale, R. J. (197I). Lancet i, I43.

Newey, H., Sanford, P. A. \& Smyth, D. H. (1970). F. Physiol., Lond. 208, 705.

Olsen, W. A. \& Ingelfinger, F. J. (I968). F. clin. Invest. 47, I I 33.

Peters, T. J. (1970). Biochem. f. 120, 195.

Stanfield, J. P., Hutt, M. S. R. \& Tunnicliffe, R. (1965). Lancet ii, 5 I9.

Steiner, M., Farrish, G. C. M. \& Gray, S. J. (1969). Am. F. clin. Nutr. 22, 87 I.

Steiner, M. \& Gray, S. J. (r969). Am. F. Physiol. 217, 747.

Taylor, J. F. \& Kyalwazi, S. K. (I972). In Medicine in a Tropical Environment p. 213 [A. G. Shaper, J. W. Kibukamusoke and M. S. R. Hutt, editors]. London: British Medical Association.

Wiseman, G. (1971). In Metabolic Processes in the Foetus and Newborn Infant [J. H. P. Jonxis, H. K. A. Visser and J. A. Troelstra, editors]. Baltimore: Williams \& Wilkins.

Woodd-Walker, R. B., Hansen, J. D. L. \& Saunders, S. J. (1972). Acta paediat., Stockh. 6r, I40. 